\title{
RELATIONSHIP BETWEEN IN-STORE PROMOTIONS AND CONSUMER BEHAVIOUR IN SHOPPING MALLS IN SOUTH AFRICA
}

\author{
Prof Vinessa Naidoo' ${ }^{1}$ ORCID: 0000-0002-2358-5588 \\ Ms Nkhumeleni Mathivha² ORCID: 0000-0001-6605-0842
}

\begin{abstract}
:
Promotions of products and services close to the point of purchase is a reality to many companies. These promotions include the demonstration of products, price discounts and free samples. This paper sets out to determine the influence of in-store promotions on consumer behaviour. The study sampled 200 middle-of-the-month and month-end shoppers in four of the largest shopping malls in Polokwane, South Africa among. The paper was designed along quantitative method dicta and the primary data were collected by means of a questionnaire. Data were analysed via IBM Statistical Package for the Social Sciences (SPSS) software, and presented in graphs and tables for easy interpretation. The results and knowledge gained from this study add to the existing body of knowledge in the discipline, and it might assist shop managers in finding the most suitable methods for in-store promotions. All ethical requirements were considered during the course of the study. The outcome of the study indicated a statistically significant relationship between consumer behaviour and in-store coupon offers. However, the association analysis results for the enjoyment of in-store promotions, in-store free samples, in-store buy-one-get-one-free offers, and in-store price discounts, failed to provide any evidence of association with consumer behaviour.
\end{abstract}

Keywords: Consumer behaviour, coupons, discount, free samples, in-store promotions, product demonstrations

\section{Introduction}

In-store promotions were found to directly influence consumers' purchase intentions and behaviours. These promotions are increasingly utilised as marketing communication techniques that target specific consumer segments to increase the sales of products and services (Kotler \& Keller, 2016) by temporarily changing a brand's perceived value. Very little research has been conducted on consumer behaviour with regard to in-store promotions in an emerging market such as South Africa.

The lack of understanding of customer shopping patterns and behaviour is evidenced by the understocking of preferred products, poor packaging of service offerings, and sub-standard after-sales services. More knowledge on this subject will assist companies to identify key variables that influence consumer behaviour and that align them to the company's strategic objectives. The need to maintain a competitive advantage further necessitates increased investment in understanding the consumer behaviour by observing customer perception, cognition, preferences, and choices of in-store promotions. 


\section{Background}

The global economic recession has negatively impacted the retail sector through slow growth and fickle shoppers (De-Marchi, Lee, \& Gereffi, 2014). This led to heavy discounting and substantial in-store promotions, improving sales but not profit (Ben-Shabat, Moriarty, \& Neary, 2010; Deloitte Touche Tohmatsu, 2010). Companies need to plan trade promotions efficiently to maximize their effect. Promotions should be integrated into an overall marketing and key account trading strategy (Guissoni, Sanchez, \& Rodriguez, 2018).

Large global retail chains have expanded throughout South African markets. A major result has been an increase in price competition, creating a larger variety of pricing formats and promotional offers. Retailers now make use of a wide range of promotional tools to generate traffic and increase purchase levels, such as discount coupons, product displays, eye-catching signs, discounted pricing, and free additional product promotions (Heilman, Lakishyk, \& Radas, 2011; Manzur, Olavarrieta, Hidalgo-Campos, \& Farias, 2014).

In-store promotion strategies mainly refer to discounted prices, free product samples, product displays, and coupons (De-Marchi et al., 2014; Phillips, Parsons, Wilkinson, \& Ballantine 2015; Foxall, 2016). Fam, Merrilees, Richard, Jozsa, Li, \& Krisjanous (2011) investigated available in-store marketing options, based on their strategic marketing objectives that is either a high-profile marketing strategy or a discount marketing strategy. In a highprofile marketing strategy, high-end value customers and prestigious clients are targeted by creating high brand value and pricing power. A discount marketing strategy, on the other hand, uses discount pricing to sell low-priced products in high volumes (Fam et al., 2011).

Some supermarkets rely more on product quality, assortments, and conservative price promotions to attract different markets. These groups often refuse to modify price promotions daily to match those who rely primarily on price discounting to stimulate sales. Trade promotions, which are backed up by special in-store displays and advertising, proved to generate an increased sales volume of up to ten times more during the promotional period than those unsupported by in-store activity (Manzur et al., 2014). Research found that many purchases are based on the retrieval of explicit memories of an advertisement, while others are based on implicit memories (De-Chernatony \& Martinez, 2013). Impulse buying may therefore be triggered by unconscious memories of advertising, reaching consumers through a variety of promotional channels (Hultén \& Vanyushyn, 2014).

Ernst \& Young (2018) suggested that manufacturers are very concerned about the spiralling costs of trade promotional expenditure, while they have very little understanding of their return on investment. Some of the in-store promotion strategies include price, samples, product displays (demonstrations), and coupons. Price promotions refer to a reduced price for a given quantity, or an increased quantity available at the same price, thereby adding value and creating an economic incentive to purchase (Huang, Chang, Yeh, \& Liao, 2014). Two methods of offering competitive pricing, recognised by consumers as signals of low prices, are EDLPs and PMGs (White \& Yuan, 2011; Foxall, 2016). EDLP refers to a constant, lower, everyday price with no temporary price discounts. These may also serve as signals of the nature or integrity of the advertised price. A PMG seller promises to match the lowest price that consumers can find elsewhere within a designated period.

Price promotion strategies are ongoing in nature rather than time-limited offers. They do not try to create a sense of urgency or immediacy to prompt a purchase. Their implicit underlying assumption is that most consumers do not want to spend too much time finding the lowest available price (Lindsey-Mullikin \& Petty, 2011). Pricing and promotions are at the heart of the free market economic system.

Sampling is an effective way to introduce a new product or create new excitement for an existing one. Heilman et al. (2011) and Manzur et al. (2014) presented some of the first known field studies that examined the effect of samples on consumer behaviour. It mainly occurs in a public setting at the point of purchase, and it may be affected by a variety of environmental or situational factors such as the way in which the sample is presented, the presence of other promoters, and whether the consumer was planning a purchase in that specific category that day. One obstacle of in-store sampling is the lack of control over who ultimately receives the promotion (Heilman et al., 2011). Understanding consumers' motives for accepting or rejecting free in-store samples can be advantageous to marketers to increase the trial rate of such promotions. Heilman et al. (2011) further suggested that trial rates for free samples might increase if the samples were distributed at appropriate times, for example, food samples can be distributed right before lunch or dinner. It might also be more effective on days when consumers are more likely to purchase in a specific category, such as products with shorter inter-purchase cycles. 
In-store product displays refer to product demonstrations and signage that draw attention to certain items and special offers. The positive effect of these promotions on impulse buying is confirmed in many studies (Peck \& Childers, 2006; Puccinelli, Goodstein, Grewal, Price, Raghubir, \& Stewart, 2009). Studies indicated that impulse buying is not only due to in-store stimuli of product demonstrations (Stilley, Inman, \& Wakefield, 2010), but that other promotional activity is vital in inducing such purchases. Consistent with the industry adage that unseen is unsold, the belief is that seeing an advertisement about a product might cause implicit memories, which might affect impulse buying.

Retailers found that over $50 \%$ of mall shoppers make impulse purchases (Dawson \& Kim, 2010). To increase the number of such purchases, retailers work with store designs, package designs, and product displays to attract shoppers' attention (Lee \& Kacen, 2008; Pentecost \& Andrews, 2010). In-store promotion facilitates knowledge on impulse buying behaviour by examining the product-specific impulse tendency, which is defined as the degree to which consumers make impulse purchases of a particular product category (Soars, 2009).

Coupons are certificates that give buyers a saving when they purchase specified products (Kotler \& Armstrong, 2018). Consumers who search for product information, appear to be particularly susceptible to coupons offering price-discounts. Hence, envelopes and flyers signalling discounted prices, might attract these shoppers to the store (Hultén \& Vanyushyn, 2014). Retailers often devote one day or more each week to circulate coupons as an alternative to in-store promotions.

Kotler and Armstrong (2018) defined consumer behaviour as the buying behaviour of final consumers, individuals, and households who buy goods and services for personal consumption. Consumer behaviour includes all the related activities of consumers, from the pre-purchase phase when they choose a product or service, through to the post-purchase phase (Schiffman \& Kanuk, 2010; Solomon, 2010). It can also be described as a multitude of mental and physical processes associated with consumer decision-making. Companies make use of consumer promotions to increase trials, attract brand switchers, motivate price-sensitive buyers, encourage repeat usage, or to provide added value. The effects of price promotions in different industries may differ due to the various characteristics of the products (Huang et al., 2014). Prior research investigated how unilateral promotions affect consumer store choice behaviour (Phillips et al., 2015). However, few researchers examined the effect of price promotion strategies on consumer price perceptions, search behaviour, and purchase intentions (Dawes, 2018; Gielens \& Gisbrechts, 2018).

Search behaviour refers to the actions of consumers in need of a product (Hofacker, 2016). They can either buy the product immediately from a previously identified store, or they can search for alternative offers. Consumers, however, incur costs during the search with regard to time, mental and physical effort, and travelling costs. Although a thorough search might lead to the lowest priced product, the cost of the search increases. Therefore, one goal of price promotion strategies is to reduce consumer search behaviour by changing the mind of the consumer in search of low prices (Gielens \& Gisbrechts, 2018). Consumers do not always check prices, because they believe that the limited total saving is not worth the time or effort (Yeo \& Calantone, 2015). Consequently, perceived price levels in stores constitute an important competitive tool for retailers. Various studies indicated a store's perceived price level as either the first or the second most important patronage criterion (Gauri, Ratchford, Pancras, \& Talukdar, 2017; Dawes, 2018).

Studies further showed that most consumer decisions are only made in store, with up to two-thirds of brand decisions that are made in store. This is particularly true for supermarket purchases, but also applies to other retail categories (Dutta, Biswas, \& Grewal, 2011; Gauri et al., 2017; Guissoni et al., 2018). The most influential factors of instore purchase decisions have been identified as reduced prices, in-store promotions, displays, store atmosphere, service, stockouts, and store layout (Alvarez \& Casielles, 2005; McWilliams \& Gerstner, 2006).

Consumers generally perceive a certain amount of risk in trying a new product (Lamb, Hair, Mcdaniel, Boshoff, \& Terblanche, 2009). Studies in the popular press on in-store sampling found that $92 \%$ of consumers would rather be presented with a free sample, than with a discount coupon while in the store. Nearly $70 \%$ of shoppers will try an in-store sample if approached, and $37 \%$ will buy a product once sampled. In-store samples can increase sales of the sampled product by as much as 300\% on the day of the promotion (Heilman et al., 2011). These findings offer that new products have a high trial rate, and sampling is an effective method to encourage trial among consumers (Vlachvei, Notta, \& Ananiadis, 2009). 
When shoppers are pressurised for time, they tend to make more unplanned purchases. Therefore, they tend to respond more positively to the various elements of promotional campaigns. Proposals of Stilley et al. (2010) and Islam (2016) indicated that the effectiveness of a shop's in-store promotion is dependent on synergies with advertising messages, making it attractive for consumers to visit the shop. One applicable generalisation from literature is that consumers are highly amenable to contextual cues in information supplied in price offers. This may motivate apparent irrational decisions (White \& Yuan, 2011; Hardy, Macrury, \& Powell, 2018). Based on an economic interpretation, consumers' perceptions of prices are influenced when the saving is obtained, as well as the effort to get it. Research particularly found that consumers' future price expectations are higher after redeeming coupons, because the savings are not realised immediately and they entail considerably more effort on the part of the consumers. Jia, Yang, Lu, \& Park (2018) found that the relationship between coupon face value and consumer spending level may not always be intuitively positive.

In-store promotions such as a 50\% discount, have been identified as offering the lowest expenditure and greatest saving for the consumer in terms of total expenditures. It also offers the consumer freedom of choice in how to allocate these savings, because unlike the volume and mixed offers, the consumer is not forced to buy more or accept more products to take advantage of the deal. Gauri et al. (2017) disputed that heavily discounted items will lead to additional store traffic, especially when the featured categories are high-penetration products. Promotions of branded items are found to be more effective than promotion of unbranded items. These discount offers could therefore affect store preference significantly.

Buy-one-get-one-free promotions appeal differently to customers, based on how they perceive it (Lim et al., 2016). An extra-product promotion such as buy-one-get-one-free, might be perceived more favourably than a mixed promotion, such as buy-two-at-50\%-discount, to buyers who do in fact distinguish between the two. Dawes (2018) suggested that consumers perceive deals that are framed as presenting gains ('. . get-one-free') as more attractive than those that are framed as reducing losses ('... 50\% discount').

Hultén and Vanyushyn (2014) found that consumers with a positive attitude towards direct-mail marketing and television commercials also respond positively to in-store promotion. Hence, there are interactive effects among the three promotional channels that increase shoppers' general impulse purchase tendencies. The frequency of exposure to in-store promotions also has a significant effect on this tendency. In the USA, nearly half of the large retailers are making use of price promotions (Borges \& Babin, 2012). Since EDLP and PMGs are easy to copy, their use increases, making the low-price signal less distinctive. Borges and Babin (2012) therefore suggested that the increase in signals will reduce consumer perception of low prices, but it will make them more aware of potential price heterogeneity and search benefits. Therefore, search actions might increase, preventing immediate purchase intentions and minimising the positive effects of price promotion strategies in creating differentiation.

A few empirical studies reported that price promotions had a positive effect on perceived quality and brand evaluations. On the other hand, some researchers have argued that there is no significant relationship between price promotions, repeat-purchase behaviour, and brand evaluation (Huang et al., 2014). Possible explanations for these inconsistent findings may include differences in product categories, the nature of the promotional activities, and consumer characteristics (Montaner \& Pina, 2008). Seven key marketing activities were found to distinguish high and low performance retailers regarding in-store promotions, namely distribution, market research, setting prices, finance, product management, promotional channels, and matching products to consumers.

Consumer experience may also moderate the effects of price promotions. Shen et al. (2007) found that loyalty had a moderating effect on price promotions. Price incentives can enhance the brand effect on high-loyalty consumers of a non-prestigious brand. However, they can decrease the brand effect on high-loyalty consumers of a prestigious brand. Price incentives had no impact on the brand effect on the low-loyalty consumers of prestigious and nonprestigious brands (Huang et al., 2014).

A study by Heilman et al. (2011) suggested that free sampling is very effective in inducing trial, especially among lower educated consumers. For consumers who are planning to buy a product in the promoted category, free sampling can encourage switching from the planned to the promoted brand. For consumers who did not have such plans, free sampling can draw them into the category and encourage category purchase. The interaction between the promoter and samplers, and among samplers, also seems to boost post-sample purchase occurrence. The study also found that although most consumers look forward to free samples, there was no indication that free samples enhance consumers' perceptions of the stores that provided them. 
Hultén and Vanyushyn (2014) investigated the effects of promotion in France and Sweden. The responses to interactive effects between internal and external promotion sources indicated that the positive recall of commercials might evoke latent wants when the products are on display in the store. There is also evidence that touching products and trying on clothes in a shop can increase the likelihood of a shopper making an impulse purchase (Peck \& Childers, 2006; Soars, 2009). Research thus identified that there is a relationship between the consumers' positive response to in-store promotion and their general impulse purchase tendency.

A meta-analysis from DelVecchio, Hernad and Freling (2006) suggested that sales promotion can either increase or decrease post-promotion brand preferences, depending on characteristics of the sales promotion and the promoted product. Nusair, Yoon, Naipaul and Parsa (2010) also indicated that the type of service or product was a critical factor in consumer perceptions of price discounts. Yoon Laurent, Fung and Gonzalez (2005) further confirmed that consumers perceived and evaluated price promotions differently in hospitality and non-hospitality industries. Montaner and Pina (2008) also observed that the effect of price promotions on consumers' evaluations of brand image, was moderated by the product category (Huang et al., 2014).

Research on the effects of in-store promotions on consumer brand evaluations has yielded contrasting results. Some studies have shown distinctly negative effects of in-store promotions on consumer quality and satisfaction evaluations, whereas others have shown positive or non-existent effects (Huang et al., 2014; Phillips et al., 2015). The question of the effect that in-store promotions have on the perceptions and purchase intentions of South African consumers, remains unanswered. It is in this context that the current study examined the effects on consumer behaviour of everyday low prices (EDLP) and price matching guarantees (PMG). Other considerations were free samples, product displays, and coupons that were used as in-store promotion strategies in Polokwane malls in South Africa (Heilman et al., 2011; Manzur et al., 2014).

\section{Aims}

The primary objective of the study is:

- To determine the relationship between in-store promotions and consumer behaviour at selected malls in Polokwane.

The secondary objectives for the study are:

- To examine whether shoppers' response to promotional offers varies across the different types of instore promotions regarding coupons, price discounts, free samples, buy-one-get-one-free, and product demonstrations.

- To examine the consumers' preferences in relation to in-store promotions.

\section{Methods}

The researcher adopted an empirical quantitative study approach. The study is cross-sectional and longitudinal as data collection took place in the middle and at the end of the month over two months. Survey research was used for the study by posing a series of questions from structured questionnaires to shoppers concerning their opinions of instore promotions in the selected shopping malls. The study subscribed to the objectivist approach as an anchoring paradigm to provide direction to the course of the investigation. Specifically, the post-positivist philosophy was embraced as a sound paradigm for the collection, assimilation, analysis, presentation, and interpretation of the research findings.

The population targeted for this study was shoppers in selected shopping malls in Polokwane. The sample consisted of 200 shoppers (100 female and 100 male consumers) at four popular malls in Polokwane with in-store promotional activities. A minimum sample size of 196 shoppers was required with an expected sampled proportion of $15 \%$, a margin of error of $5 \%$, and a confidence level of $96 \%$. The sample size was adjusted to 200 shoppers to accommodate the non-responses.

The primary data were collected through mall intercept surveys. This entailed engaging shoppers in a shopping mall, qualifying them, and thereafter, conducting the interview. Data collection was done in the middle and at the end of the month. The questionnaire obtained the following information:

- Opinions of shoppers on how in-store promotions influence their buying behaviour, specifically their brand loyalty and brand switching.

- Purchase acceleration, stockpiling, product trial, as well as preferred products or services to be promoted using in-store promotions.

- The shopping and demographic profiles of the respondents. 
The analysis of the survey data was conducted using the SPSS. To measure the association between independent and dependent variables, which are both categorical in nature, the Chi-square test was employed. Reliability refers to the ability of a research instrument to continuously render similar results (Heale \& Twycross, 2015). The authors identified three attributes or qualities that infer reliability, namely stability, homogeneity, and equivalence (Heale \& Twycross, 2015). This study tests these attributes through the survey instrument. This study ensured validity by utilising a well-structured questionnaire that was administered to all the participants, and that successfully and consistently gathered the same type of data from the survey participants.

Research ethics can be defined as the standards of the researcher's behaviour in relation to the rights of those who become the subjects of a research project or who are affected by it (Saunders et al., 2012:680).

- The researcher focused on the research questions and did not interfere in any way that could jeopardize the integrity of data or the study as a whole.

- The researcher was the only resource for data collection and the identities of the respondents are protected. There were no unpleasant or damaging effects on the individual, the team, or the workplace.

The study developed a framework from existing literature with which to assess consumer behaviour. Only components pivotal to this research were involved. The developed structure is not exhaustive and it creates the opportunity for future research in the area of consumer behaviour. The sample size of the study is relatively small and targeted only four malls. This makes it difficult to find significant relationships, as statistical tests require larger sample sizes to ensure a representative distribution of the population.

\section{Results}

Figure 1 shows the distribution of respondents among the four targeted malls in Limpopo. Most of the participants were shopping at the Limpopo Mall, (42.5\%). This was followed by the Mall of the North (28\%), Savanna Mall (18\% and finally, Lebowakgomo Mall (11.5\%). Slightly more females took part in the study (53\% to 47\%) and most participants (63.5\%) belonged to the youngest age group - 18 to 25 years old, with $46.5 \%$ with a matric qualification, diploma, or degree as the highest qualifications. The participants mostly belonged to the lower income group, with 62.5\% earning less than R5 001 per month.

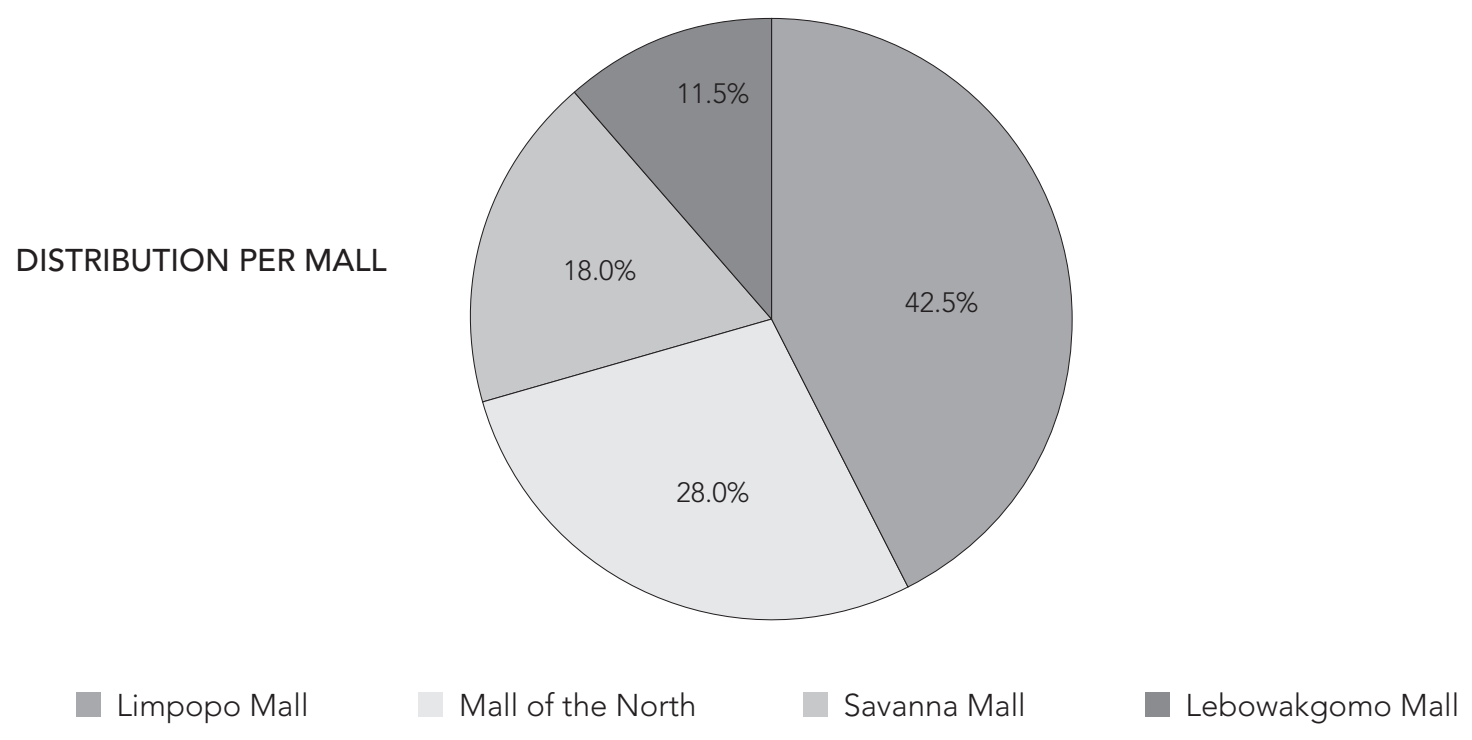

Figure 1: Distribution within the targeted malls

Primary data was collected and used in the investigation and analysis of the association between in-store promotions and consumer behaviour. For the analysis to be affected efficiently, appropriate data extraction was carried out to isolate the questions that were most aligned with the research questions. The participants' feedback was coded and analysed using the SPSS analysis toolkit.

From the research topic it is expected that consumers will adjust their purchasing habits based on the promotional strategies adopted in stores. It therefore suffices to have consumer behaviour as the dependent or outcome variable, since it might highlight the different shifts due to in-store promotions. The statement from the questionnaire that was deemed the most appropriate was: I am a person who makes unplanned purchases? The results indicated that most of the respondents (61\% in total) agreed to some extent with this statement, while 39\% disagreed. 
The independent variables were chosen, based on the in-store promotion strategy they referred to. The responses were categorical in nature and were guided by a 6-point Likert scale, with $1=$ completely disagree and $6=$ completely agree. A total of five explanatory variables were selected and questions that closely matched these variables were identified and analysed. These five variables that were investigated with the most appropriate questions and the recorded responses were:

- I enjoy in-store promotion environments.

- A coupon has allowed me to buy more quantities of the same product.

- I choose my grocery store based on the free samples they provide.

- A buy-one-get-one-free has led me to buy the product earlier than planned.

- I have favourite brands, but most of the time I buy a brand that offers price discount.

Cronbach's alpha was used to measure the reliability of the questionnaire that was used to collect the primary data. The questionnaire had a total of 14 items, but only 13 were assessed. Cronbach's alpha was not computed for the question: Do you use in-store promotional free samples? This is because, unlike the other 13 questions, this question is not a scale question or statement, but rather a dichotomous question with only two possible answers.

The Cronbach's alpha computed for the 13 items as shown in Table 1. The alpha value for the question, A buy-oneget-one-free has led me to buy the product earlier than planned, amounted to 0.5951 , and it was the only item valued less than 0.60 . The alpha values for the other statements ranged between 0.6056 and 0.6765 . None of the statements valued above 0.70 . The overall test scale alpha value was 0.6576 , which means that the reliability of the 13 statements were moderately acceptable.

Table 1: Cronbach's alpha calculation for thirteen questionnaire items

\begin{tabular}{|c|c|c|c|c|c|c|}
\hline ITEMS & OBSERVATION & SIGN & $\begin{array}{c}\text { ITEM-TEST } \\
\text { CORRELATION }\end{array}$ & $\begin{array}{c}\text { ITEM-TEST } \\
\text { CORRELATION }\end{array}$ & $\begin{array}{c}\text { AVERAGE } \\
\text { INTER-ITEM } \\
\text { CORRELATION }\end{array}$ & ALPHA \\
\hline $\begin{array}{c}\text { Q1. I enjoy the in-store } \\
\text { promotion environment. }\end{array}$ & 200 & + & 0.3632 & 0.1991 & 0.1356 & 0.6531 \\
\hline $\begin{array}{c}\text { Q2. I am a person } \\
\text { who makes unplanned } \\
\text { purchases. }\end{array}$ & 200 & + & 0.2163 & 0.0434 & 0.1484 & 0.6765 \\
\hline $\begin{array}{c}\text { Q3. When I see something } \\
\text { that } \\
\text { really interests me, I buy } \\
\text { it without considering the } \\
\text { consequences. }\end{array}$ & 200 & + & 0.4226 & 0.2646 & 0.1304 & 0.6428 \\
\hline $\begin{array}{c}\text { Q4. I avoid buying things } \\
\text { that are not on my shopping } \\
\text { list. }\end{array}$ & 200 & + & 0.2560 & 0.0846 & 0.1449 & 0.6704 \\
\hline $\begin{array}{c}\text { Q6. A coupon has allowed } \\
\text { me to buy another brand, } \\
\text { which I do not regularly buy. }\end{array}$ & 200 & + & 0.4165 & 0.2578 & 0.1310 & 0.6439 \\
\hline $\begin{array}{c}\text { Q7. A coupon has allowed } \\
\text { me to buy more quantities } \\
\text { of the same product. }\end{array}$ & 200 & + & 0.3794 & 0.2169 & 0.1342 & 0.6503 \\
\hline $\begin{array}{c}\text { Q8. If a brand offers a price } \\
\text { discount, that could be a } \\
\text { reason for me to buy it. }\end{array}$ & 200 & + & 0.4670 & 0.3147 & 0.1265 & 0.6349 \\
\hline $\begin{array}{c}\text { Q9. When I buy a brand } \\
\text { that had a discounted price, } \\
\text { I feel that I am getting a } \\
\text { good buy. }\end{array}$ & 200 & + & 0.4895 & 0.3404 & 0.1246 & 0.6307 \\
\hline $\begin{array}{c}\text { Q10. I choose my grocery } \\
\text { store based on the free } \\
\text { samples they provide. }\end{array}$ & 200 & + & 0.3874 & 0.1335 & 0.6490 \\
\hline
\end{tabular}


Table 1: Cronbach's alpha calculation for thirteen questionnaire items (CONTD.)

\begin{tabular}{|c|c|c|c|c|c|c|}
\hline ITEMS & OBSERVATION & SIGN & $\begin{array}{c}\text { ITEM-TEST } \\
\text { CORRELATION }\end{array}$ & $\begin{array}{c}\text { ITEM-TEST } \\
\text { CORRELATION }\end{array}$ & $\begin{array}{l}\text { AVERAGE } \\
\text { INTER-ITEM } \\
\text { CORRELATION }\end{array}$ & ALPHA \\
\hline $\begin{array}{l}\text { Q11. I do my grocery } \\
\text { shopping when I know there } \\
\text { will be free samples. }\end{array}$ & 200 & + & 0.4518 & 0.2974 & 0.1279 & 0.6376 \\
\hline $\begin{array}{l}\text { Q12. A buy-one-get-one- } \\
\text { free has led me to buy } \\
\text { the product earlier than } \\
\text { planned. }\end{array}$ & 200 & + & 0.6669 & 0.5518 & 0.1091 & 0.5951 \\
\hline $\begin{array}{l}\text { Q13. A buy-one-get-one- } \\
\text { free has led me to buy } \\
\text { more quantities of the same } \\
\text { product. }\end{array}$ & 200 & + & 0.6170 & 0.4907 & 0.1135 & 0.6057 \\
\hline $\begin{array}{l}\text { Q14. I have favourite } \\
\text { brands, but most of the } \\
\text { time I buy a brand that } \\
\text { offers price discount. }\end{array}$ & 200 & + & 0.6176 & 0.4914 & 0.1134 & 0.6056 \\
\hline Text scale & & & & & 0.1287 & 0.6576 \\
\hline
\end{tabular}

Chi-square analysis was employed to determine the relationship between in-store promotions and consumer behaviour. Cross tabulation tests were performed to establish the strength of such relationships. The results of Question 2, as the dependent variable, and Questions 1, 7, 10, 12 and 14, as the independent variables, were used for the analysis.

Table 2 presents the chi-square and p-value for each set. From these results, only one relationship has been identified, namely the influence of in-store coupon promotions on consumer behaviour, with a p-value of 0.04 , which is below the critical value of 0.05 . As a result, it is concluded that there is a statistically significant association between consumer behaviour and in-store coupon offers, i.e. consumers who buy more quantities of the same product as a result of coupons tend to elicit a similar behaviour with regard to making unplanned purchases.

Table 2: Cross-tabulation results

\begin{tabular}{|c|c|c|}
\hline RELATIONSHIP & CHI-SQUARE & P-VALUE \\
\hline Q2 vs Q1 & 25,061 & 0,459 \\
\hline Q2 vs Q7 & 38,357 & 0,310 \\
\hline Q2 vs Q10 & 27,955 & 0,283 \\
\hline Q2 vs Q12 & 28,563 & 0,186 \\
\hline Q2 vs Q14 & 31,099 & 0 \\
\hline
\end{tabular}

The results from the statistical analysis indicated that there was no association between consumer behaviour and enjoyment of in-store promotions. Lindsey-Mullikin and Petty (2011) pointed out that many consumers do not want to spend too much time finding the lowest available price. Based on the literature and the study results, it could therefore be concluded that the level of enjoyment consumers derived from in-store promotions does not influence their purchase behaviour.

\section{Discussion}

From the five different strategies of in-store promotions investigated in this study, the only statistically significant association was found between consumer behaviour and coupon offers. This is in line with the literature by Hultén and Vanyushyn (2014), who suggested that consumers who engage in information search, appear to be particularly 
susceptible to coupons offering price discounts. The significance of coupons are also supported by Kotler and Armstrong (2018), who found that coupons can promote early trial of a new brand, or stimulate sales of a mature brand. This result, however, opposes the findings of Jia et al., (2018), who indicated that the relationship between coupon face value and consumer spending level may not always be intuitively positive.

The research evidenced no statistically significant association between free samples offered in stores and consumer behaviour. This finding contradicts the findings of Ho, Ganesan, and Oppewal (2012). Based on the literature by Lamb et al., (2009) and Heilman et al. (2011), the value of free samples is in exposing customers to new products or brands, therefore, overcoming the perceived risk in trying unknown products. According to Ofosu-Boateng (2020) and Heilman et al. (2011), a shortfall of free samples is a marketer's lack of control over who ultimately receives the promotion.

With regard to buy-one-get-one-free offers, the findings indicated no statistically significant relationship with consumer behaviour. The study found this result particularly interesting, because this offer implies a 50\% discount and the expectation is that consumers would react positively to the promotion. Literature by Dawes (2018) indicated that the presentation of this offer influenced the perception of the customer either as a real gain, or as a reduced loss.

No significant statistical association was found between consumer behaviour and in-store price discounts. According to Johnen and Schnittka (2020), everyday low prices involve setting lower average prices and eliminating, or at least strongly reducing, the difference between regular and promotional prices. The result could imply that if the discount is not enticing enough, the pattern of the consumer behaviour will not be altered.

Finally, for the variable relating to product demonstration as in-store promotions, the research study found no evidence that would imply any association with consumer behaviour. The findings could imply that the timing of the promotion plays a role, as found by Gurau and Tinson (2003) and Sheehan and Van Ittersum (2001), regarding customers' responses to Christmas displays.

\section{Conclusions}

From the results of the study, coupons are the most effective promotional offer. Store managers could make use of this method to increase immediate sales and draw customers to their stores. Based on the literature by Manzur et al. (2014), the promotions must be backed up by store activity, such as attractive displays and ensuring sufficient availability of products.

It is further recommended that alternative methods of in-store promotions should not be abandoned, but that managers should find ways to improve these methods. For example, a free sample of the product offered by a coupon, might assist a customer to overcome their fear of an unknown product and motivate purchases. Managers should also identify the actual customer and ensure that promotional offers reach the correct target market.

White and Yuan (2012) suggested that promotions should be integrated into an overall marketing and key account trading strategy. These promotions should be customer-centric and should lead to customer retention and reinforce brand loyalty. Managers should therefore carefully review the success and failure of past promotions to identify the value, focal point, and timing of future promotions.

The study contributes to knowledge on the relationship between in-store promotions and customer behaviour. The use of coupons was identified as the most successful method of in-store promotions. Managers could make use of the findings of this study to better plan their promotional offers for increased results. This study set out to determine the influence of in-store promotions on customer behaviour. It was found that the offer of coupons is the most significant method of promotions.

This study merely scraped the surface of this topic. Future research in the field can be conducted in a much wider geographical setting to establish the influence of location on in-store promotions. The demographical information and income could also be used as influencing factors. A qualitative study in this field could further explain the reasons why customers are not influenced to the extent that one would expect, by factors such as the buy-one-getone-free offer. 


\section{Acknowledgements:}

We would like to sincerely thank the Tshwane University of Technology for making this study possible.

\section{References}

Alvarez, A.B., \& Casielles, R.V. (2005). Consumer evaluations of sales promotion: The effect on brand choice. European Journal of Marketing, 39(1):54-70.

Ben-Shabat, H., Moriarty, M., \& Neary, D. (2010). Expanding opportunities for global retailers. Chicago, ILL.: Kearney. Blakeman, B. (2014). Integrated marketing communication. Creative strategy from idea to implementation. Plymouth: Rowman \& Littlefield.

Borges, A., \& Babin, B. (2012). Revisiting low price guarantees: Does consumer versus retailer governance matter? Marketing Letters, 23(3):777-791.

Dawes, J. (2018). Price promotions: examining the buyer mix and subsequent changes in purchase loyalty. Journal of Consumer Marketing, 35(4):366-376.

Dawson, S., \& Kim, M. (2010). Cues on apparel web sites that trigger impulse purchases. Journal of Fashion Marketing and Management, 14(2):230-246.

De-Chernatony, B., \& Martinez, E. (2013). Examining the role of advertising and sales promotions in brand equity creation. Journal of Business Research, 66(1):115-122.

Deloitte Touche Tohmatsu. (2010). Retail Sales Grow Despite Recession, but Profits Take a Hit. Deloitte, Die gem.

Delvecchio, D., Hernad, D., \& Freling, T. (2006). The effect of sales promotion on post promotion brand preference: A meta-analysis. Journal of Retailing, 82(3):203-213.

De-Marchi, V., Lee, J., \& Gereffi, G. (2014). Globalization, recession and the internationalisation of industrial districts. Experiences from the Italian gold jewellery industry. European Planning Studies, 22(4):886-884 .

Drost, E.A. (2011). Validity and reliability in social science research. Education Research and Perspectives, 38(1):105124.

Duncan, T. (2011). IMC: Using advertising \& promotion to build brands. 2nd ed. Boston: McGraw-Hill.

Dutta, S., Biswas, A., \& Grewal, D. (2011). Regret from post purchase discovery of lower market prices: Do price refunds help? Journal of Marketing, 75(6):124-138.

Fam, K.S., Merrilees, B., Richard, J.E., Jozsa, L., Li, Y., \& Krisjanous, K.

J. (2011). In-store marketing: A strategic perspective. Asia Pacific Journal of Marketing and Logistics, 23(2):165-176.

Foxall, G. (2016). The Routledge companion to consumer behaviour analysis. 1st ed. New York: Routledge.

Gauri, D., Ratchford, B., Pancras, J., \& Talukdar, D. (2017.) An empirical analysis of the impact of promotional discounts on store performance. Journal of Retailing, 93(3):283-303.

Gielens, K., \& Gisbrechts, E. (2018). Handbook of research and reatiling. 1st ed. Northhampton: Edward Elgar

Guissoni, L., Sanchez, J., \& Rodriguez, J. (2018). Price and in-store promotions in an emerging market. Marketing Intelligence \& Planning, 36(4):498-511.

Gurau, C., \& Tinson, J. (2003). Early evangelist or reluctant Rudolph? Attitudes towards the Christmas commercial campaign. Journal of Consumer Behaviour, 3(1):48-62

Hardy, J., Macrury, I., \& Powell, H. (2018). The Advertising handbook. 4th ed. London: Routledge.

Heale, R., \& Twycross, A. (2015). Validity and reliability in quantitative studies. Evidence-based Nursing, 18(3):66-67.

Hofacker, C. (2016). Big data and consumer behaviour: imminent opportunities. Journal of Consumer Marketing, 89-97.

Huang, H., Chang, Y., Yeh, Y., \& Liao, C. (2014). Promote the price promotion: The effects of price promotions on customer evaluations in coffee chain stores, International Journal of Contemporary Hospitality Management, 26(7):1065-1082.

Heilman, C., Lakishyk, K., \& Radas, S. (2011). An empirical investigation of in-store sampling promotions. British Food Journal, 113(10):1252-1266. 
Ho, H., Ganesan, S., \& Oppewal, H. (2012). The impact of store-price signals on consumer search and store evaluation. Journal of Retailing, 87(2):127-141.

Hultén, P., \& Vanyushyn, V. (2014). Promotion and shoppers' impulse purchases: the example of clothes. Journal of Consumer Marketing, 31(2):94-102.

Islam, S. (2016). Internal marketing practice in services organization. A case study of an advertising agency. Proceedings from: Global Marketing Conference at Hong Kong. Hong Kong.

Jia, H., Yang, S., Lu, X., \& Park, C. (2018). Do consumers always spend more when coupon face value is larger? The inverted U-shaped effect of coupon face value on consumer spending level. Journal of Marketing, 82(4):70-85.

Johnen, M., Schnittka, O. (2020). Changing consumers' minds at the point of sale: price discounts vs. in-store advertising. Mark Lett 31: 49-71. https://doi.org/10.1007/s11002-020-09512-0

Kotler, P., \& Armstrong, G. (2018). Principles of marketing, Global Edition. 17th ed. Essex, England: Pearson Education Limited.

Kotler, P., Armstrong, G., \& Tait, M. (2013). The principles of marketing. Cape Town: Pearson Education South Africa (Pty) Ltd.

Kotler, P., \& Keller, Kl. (2016). Marketing management. 15th ed. New Jersey: Pearson Prentice Hall.

Lamb, C.W., Hair, J.F., Mcdaniel, C., Boshoff, C., \& Terblanche, N.S. (2009). Marketing. 3rd ed. South Africa: Oxford. Lee, J.A., \& Kacen, J.J. (2008). Cultural influences on consumer satisfaction with impulse and planned purchases. Journal of Business Research, 61(3):265-272.

Lim, S., Cha, O., \& Choi, I. (2016). Buy one get one to share. Preference between bonus packs and price discounts for experiential versus material products. Advances in Consumer Research, 44:536-536.

Lindsey-Mullikin, J., \& Petty, R. (2011). Marketing tactics discouraging price search: Deception and competition. Journal of Business Research, 64(1):67-73.

Manzur, E., Olavarrieta, S., Hidalgo-Campos, P., \& Farias, P. (2014). Store price promotion strategies. An empirical study from Chile. Academia Revista Latinoamericana de Administracion, 26(3):356-372.

Nusair, K., Yoon, H., Naipaul, S., \& Parsa, H. (2010). Effect of price discount frames and levels on consumers 'perceptions in low end service industries. International Journal of Contemporary Hospitality Management, 22(6):814-835.

Ofosu-Boateng, I. (2020). Influence of Consumer Sales Promotion on Consumers' Purchasing Behaviour of the Retailing of Consumer Goods in Tema, Ghana. Journal of Marketing Management, 8 (1): 24-36.

Peck, J., \& Childers, T.L. (2006). If I touch it, I have to have it. Individual and environmental influences on impulse purchases. Journal of Business Research, 59(6):765-769.

Pentecost, R., \& Andrews, L. (2010). Fashion retailing and the bottom line. The effects of generational cohorts, gender, fashion fan ship, attitudes and impulse buying on fashion expenditure. Journal of Retailing and Consumer Services, 17(1):43-52.

Phillips, M., Parsons, A., Wilkinson, H., \& Ballantine, P. (2015). Competeing for attention with instore promotions. Journal of Retailing and Consumer Services, 26(1):141-146.

Puccinelli, N.M., Goodstein, R.C., Grewal, D., Price, R., Raghubir, P.A., \& Stewart, D. (2009). Customer experience management in retailing. Understanding the buying process. Journal of Retailing, 85(1):15-30.

Saunders, M., Lewis, P., \& Thornhill, A. (2012). Research methods for business students. 6th ed. England: Pearson Education Limited.

Sheehan, D \& Van Ittersum, K. (2001). Isolating Price Promotions: The Influence of Promotional Timing on Promotion Redemption, Journal of the Association for Consumer Research, 6 (1):1

Soars, B. (2009). Driving sales through shoppers' sense of sound, sight, smell and touch. International Journal of Retail and Distribution Management, 37(3):286-298.

Stilley, K.M., Inman, J.J., \& Wakefield, K.L. (2010). Planning to make unplanned purchases? The role of in-store slack in budget deviation. Journal of Consumer Research, 37(2):264-278.

Van Tonder, T. (2011). Product manager-transit \& tavern. Provantage Out of Home Media. 
Vlachvei, A., Notta, O., \& Ananiadis, I. (2009). Does advertising matter? An application to the Greek wine industry. British Food Journal, 111(7):686-98.

White, B., \& Yuan, H. (2011). Building trust to incease purchase intentions. The signaling impact of low price policies. Journal of consumer psychology, 1:11.

White, T., \& Yuan, H. (2012). Building trust to increase purchase intentions. The signalling impact of low pricing policies. Journal of Consumer Psychology, 22(3):384-394.

Yeo, C., \& Calantone, R. (2015). Consumer pricing information processing differences in response to firm pricing. Remembering vs reasoning. Asia Pacific Journal of Innovation and Entrepreneurship, 31-69.

Yoon, C., Laurent, G., Fung, H.H., \& Gonzalez, R. (2005). Cognition, persuasion and decision making in older consumers. Marketing Letters, 16(3-4):429-411 